governments should either be participants or effectively be represented.

For Western governments, the implications of this complicated situation are bound to be uncomfortable. In Europe, governments will have to be telling anyone who will listen that they stand by what was agreed in 1979, but that they will refuse house-room for the Pershing and cruise missiles once there is some kind of agreement at Geneva. They will have to give further hostages to electoral fortune by pointing out the inconsistencies in the Soviet Union's insistence that it must be allowed to negotiate from strength. In the United States, however, there is an urgent need that the Reagan government should change tack. More factual and less strident accounts of the Soviet threat would help the Helmut Kohls of this world, while the eagerness of members of the US Administration such as Mr Caspar Weinberger, the Secretary of Defense, to prove that the Soviet Union is "not serious" about arms control is increasingly an impediment to a successful negotiation. Western governments in 1983 should try to persuade their own people that they are equally serious in their intentions both to increase the nuclear striking power in Europe and to negotiate a deal with the Soviet Union.

\section{Max Born's centenary}

\section{Quantum mechanics is less than a century old; Max Born belongs to an earlier period.}

The accompanying photograph of the late Professor Max Born is a monument to the heroic days of modern physics. Born was born almost exactly a century ago, and his anniversary has been widely celebrated in West Germany in the past few months, the fact of his having been driven out in the 1930s notwithstanding. Max Born is still widely revered as a perceptive and sympathetic teacher, as well as the author of an important textbook on atomic physics. Some may also know that with Jordan and, later, with Heisenberg, he contributed to the construction of quantum mechanics, still the most surprising theoretical construct of the twentieth century. Born's achievement, in the early 1920s, was that or reconciling in his own mind the notion that quantum states can be likened to vectors in some $\boldsymbol{n}$-dimensional or even infinitely dimensional space, and physical quantities to operators in that

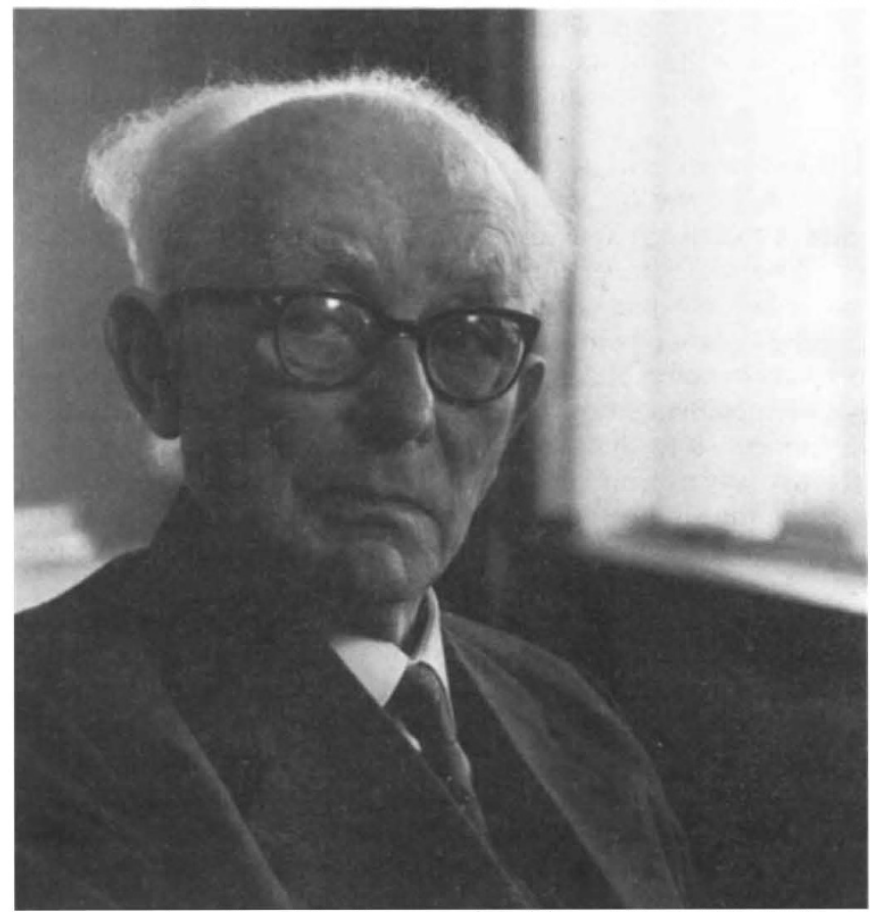

space, a triumph of logic over intuition. That Schrödinger eventually stole the show was a kind of accident. And, in any case, Max Born eventually taught physics at the University of Edinburgh as if he had never been a hero.

\section{Can there be excess TV?}

\section{Britain has changed from having too little to having too much television.}

A few weeks ago, the British were widely regarded as a televisually deprived people, stuck with a meagre ration of three television channels, two run by the British Broadcasting Corporation and one other operated on behalf of commercial interests by a public corporation called the Independent Broadcasting Authority (IBA), financed by those given a licence to broadcast television signals accompanied by advertisements. The late Lord Thomson's remark that a television franchise was a licence to print money has ever since stuck in the public mind and has also been a challenge to the statutory broadcasting authorities: how can the entrepreneurs be kept in their tradesmen's places (chairmen of commercial television companies do not automatically qualify for knighthoods in the British system) while being cajoled into producing better television broadcasts than those that the marketplace would require?

The simple answer, so far, has been to let them make profits, but to take away the cream by means of a levy over and above taxation. More recently, IBA has required that profitable television contractors should contribute towards the cost of an extra television channel. Now, however, the broadcasting authorities are in a fix. The British government, more by accident than design, has decreed not merely that there should be at least two and possibly four extra television channels by 1986 , but that there should be a national cable television system even sooner. And then, further to complicate the relief of visual deprivation, the British government has launched a fourth conventionally broadcast set of television signals among the British people, called Channel 4 by English-speaking people, but Canl Pedwar Cymru among those in Wales who are able, linguistically, to insist on speaking Welsh.

The immediate (but admittedly anecdotal) consequence of this development has been that people recently crying for more televisual choice have taken to complaining that they cannot possibly keep up with the output of four channels. Merely reading the menus on offer each day is a sufficient chore; actually watching what is on offer would be death of a kind. This, no doubt, is the reason why Channel 4 has so far been a disaster. It seems to have won the allegiance of a mere four per cent of the British televiewing audience, chiefly (it appears) on the strength of ancient films from Hollywood. What the new channel has so far failed to accomplish is the trick of making what it has to show overwhelmingly captivating for some minority among that section of the population at risk of having no other television signal at which to look. Why, in other words, has not the British Channel 4, the first national television network anywhere to be known by a number greater than three, failed in its first few weeks to live up to the ideals of its prospectus? Because it has not had the courage of its conviction that minority interests should be catered for. Science, for example, has been dealt with shabbily on the fourth television channel. On present form, the sixty-fourth channel will be no better.

The moral for the British broadcasting authorities, the British Broadcasting Corporation and the Independent Broadcasting Authority, is that they should practise what they preach, and in particular agree that as the opportunities for people to choose what they watch expand, the need that statutory authorities should oversee what people watch will inevitably decline. It is understandable but nonetheless unforgivable that the broadcasting authorities should resent the replacement of four by sixty-four channels of video signals. What they do not yet appreciate is that their present audiences are not disloyal but merely dissatisfied; they would like more choice, even if in the end they choose to watch what they have always watched, or nothing at all. If the market will bear that, is there any reason why the customers should be denied? 